$\begin{array}{llll}\text { Lembaran } & \text { Volume 12 Number 2 } & \text { ISSN: } & \text { Page } \\ \text { Sejarah } & \text { October 2016 } & 1410-4962 & 132-143\end{array}$

\title{
Penyelundupan dan Terbentuknya Kawasan Ekonomi Maritim Wakatobi Tahun 1980-an
}

\section{LA ODE RABANI}

Universitas Airlangga

\begin{abstract}
This paper explains three important factors that affected the history of Wakatobi economic area shifting in Southeast Sulawesi. First, global market commodities such as duralex, bicycles, motorbikes, mechanized boats were easier to find and came earlier in this area than other regions. Second, illegal trading (smuggling) was likely to happen because of the lax of authorities in guarding its sea areas between 1950's-1990's. Third, the capital accumulation in this area pushed the improvement of the economic infrastuctures that lead to market expansion to Eastern Indonesia.
\end{abstract}

\section{Abstrak}

Makalah ini menjelaskan tiga hal penting dalam sejarah terbentuknya kawasan ekonomi Wakatobi di Sulawesi Tenggara. Pertama, barang-barang di pasar global seperti duralex, sepeda, sepeda motor, perahu bermesin mudah ditemukan dan datang lebih awal dibanding kawasan lain. Kedua, ekonomi ilegal (penyelundupan) mudah dilakukan karena keterbatasan pengawasan negara dalam menjaga wilayah laut sejak tahun 1950-an sampai 1990-an. Ketiga, akumulasi kapital di kawasan ini mendorong peningkatan infrastruktur ekonomi perdagangan sehingga mengakibatkan ekspansi pasar ke daerah-daerah di kawasan timur Indonesia.

Keywords: smuggling; trade networking; maritime economic; Tukang Besi island

\section{Kata Kunci :} penyelundupan; jaringan perdagangan; ekonomi maritim; kepulauan Tukang Besi 


\section{Pengantar}

Ekonomi global di ruang ekonomi lokal-murah. Tetapi karena banyak, pasar baru dan orang baru mengikuti. Akses barang global dari desa ke kota dibuka oleh para pedagang Kepulauan Tukang Besi. (Kompas, 30 Juli 1975)

Tulisan ini mula-mula terinspirasi dari artikel surat kabar De Sumatra post. Dalam edisi 26 Maret 1931, disebutkan bahwa kondisi dua pulau yang ada di Wakatobi, Tomia dan Binongko, memprihatinkan. Begitu tandusnya, kayu bakarpun bahkan harus didatangkan dari luar pulau, sementara air minum diperoleh dari hasil penyaringan air payau. Meskipun demikian, keduanya memiliki tiga ratus perahu, empat puluh di antaranya dilaporkan akan segera berangkat ke Singapura.

Selanjutnya, tulisan ini juga terinspirasi dari berita-berita tentang Wakatobi dalam surat kabar lainnya. Pertama, pemberitaan SoerabaiaschHandelsblad 27 Juli 1929 tentang lima puluh calon calon haji, asal Binongko, salah satu pulau di Kepulaun Tukang Besi, yang telah berada di Mekah. Hal itu menarik karena masyarakat Binongko yang tidak memiliki sumber daya ekonomi yang baik ternyata bisa pergi berhaji dalam jumlah yang relatif tidak sedikit. Kedua, pemberitaan De Indische Courant 11 Maret 1938 tentang hukuman penjara yang dijatuhkan selama 9-10 tahun kepada penyelundup dari Binongko; La Samana, Hadji Asnawi, dan La Ramini. Mereka dihukum karena menyelundupkan ratusan peti teh ke Singapura dengan melibatkan warga Tionghoa Ang Chiang Ping. Ketiga, tajuk berjudul "Kisah Awak Perahu Lambo, Mereka yang Berpiring Duralex" dalam Kompas 11 Februari 1983. Berita ini relatif mengagetkan, sebab bagaimana mungkin masyarakat sebuah kawasan kepuluan, yang secara geografis "terpencil”, jauh dari daerah perbatasan dan arena perdagangan internasional, mampu menghadirkan barang-barang mewah untuk ukuran periode itu, serta rutin menjalankan aktivitas ekonomi di luar negeri.

Berdasarkan hal-hal tersebut, tulisan ini akan menjawab tiga hal pokok. Pertama, mengapa aktivitas ekonomi yang "tidak biasa" itu berlangsung di Wakatobi, daerah yang secara geografis jauh dari perbatasan dengan negara lain? Kedua, bagaimana respon masyarakat di sana terhadap dinamika perubahan itu? Ketiga, perubahan seperti apa yang terjadi ketika penegakan hukum dijalankan?

\section{Jejak Jaringan Ekonomi Maritim Wakatobi di Nusantara}

Aktivitas perdagangan maritim di Asia Tenggara masyarakat Tukang Besi telah lama berlangsung. Catatan pertama dan paling dekat ialah "prasasti hidup" dalam bentuk tumbuh-tumbuhan dan burung yang ada daerah itu (Heinrich Kuhn, 1903: 18-38). Di antaranya buah Malaka (Phyllanthus 
Figur 1.

Peta Kepulauan Wakatobi

Sumber: http://visitkendari. blogspot.co.id/2012/04/petawakatobi.html

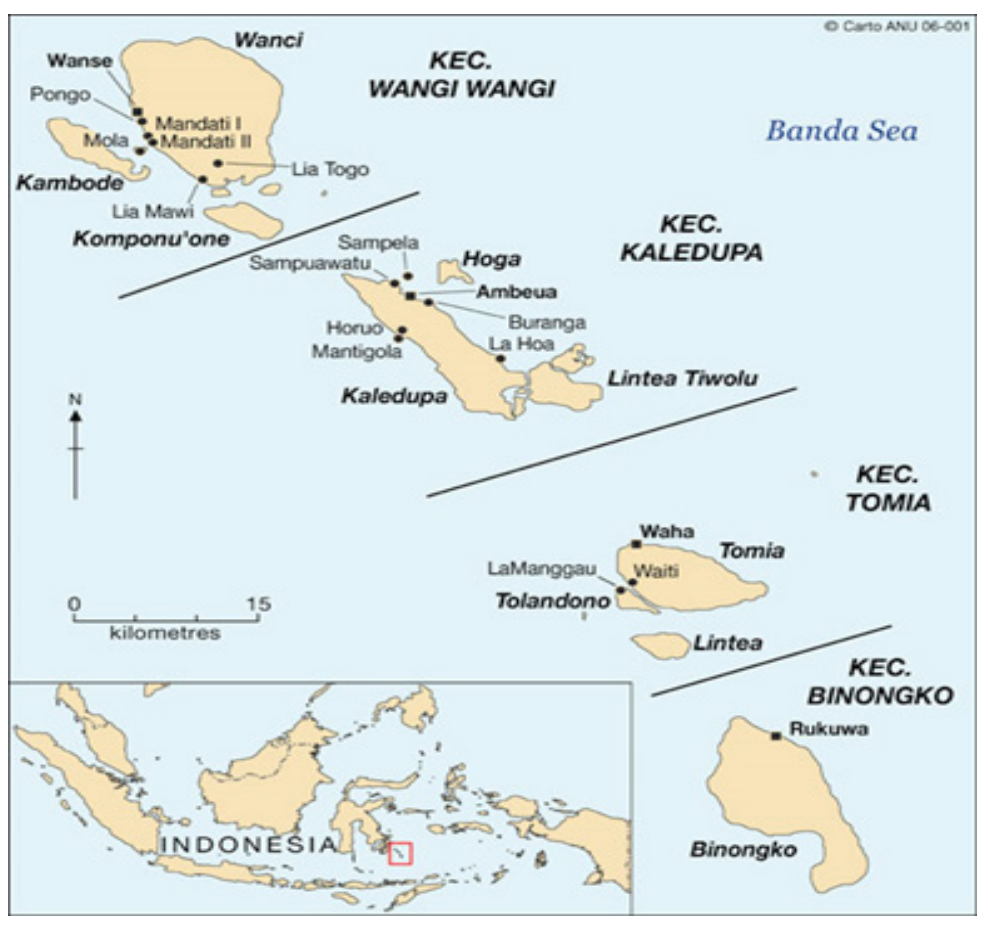

emblica), kayu Jawa (singkong), po' jupanda (jenis mangga dari Ujungpandang), serta jenis burung seperti kokokan laut (Butorides javanica) dan cangak laut (Ardea sumtrana). Berdasarkan informasi lokal, buah-buahan biasanya dinamakan berdasar asal memperolehnya, yakni dari Malaka, Melayu-Riau, dan Pulau Penang Malaysia. Adapun persebarannya hampir dapat dipastikan buah-buahan umumnya tidak hanya untuk dimakan, melainkan juga untuk keperluan pengobatan.

Selain "prasasti hidup," jaringan perdagangan maritim juga dapat dilihat dari berbagai penelitian. Analisis McKnight tentang perdagangan di Timur Indonesia, misalnya, mengungkap adanya kontak antara Buton dan Australia Utara pada abad XVIII. Namun, tidak disebut secara spesifik orangorang Buton manakah yang dimaksud Knight. Menurut hemat penulis, bila dilihat dari profesi yang dilakukan di perairan Sawu, Tual, Kepulauan Kei, Timor, dan Australia Utara sebagai pencari lola, sirip ikan hiu, mutiara, dan teripang, dapat dipastikan bahwa orang yang dimaksud ialah orang-orang Kepulauan Tukang Besi bersama orang-orang Bajo atau Bajau (wawancara dengan La Mananu September 2014). Adapun pasar dari komoditas itu adalah perusahaan-perusahaan Inggris dan China di Singapura melalui pedagang perantara-sebagian kecil orang-orang China, Jawa, Melayu, dan Bugis.

Catatan Heather Sutherland tentang komoditas teripang dan perahu Wangkang (Bangka: bahasa lokal) di abad XVII menunjukkan adanya peran orang-orang Buton dalam pengumpulan teripang di perairan Sulawesi, 
Nusa Tenggara, dan Australia Utara. Hanya saja, tulisan itu tidak merinci, komunitas Buton mana yang ikut menjadi bagian dalam aktivitas itu. Sementara Eric Tagliacozo dan Esther Velthoen yang menulis tentang persaingan politik dan perbatasan di akhir abad XIX dan awal abad XX menunjukkan pengetahuan tambahan tentang para pelaut (pelayar) dan pedagang Buton sebagai salah satu komunitas aktif di Asia Tenggara. Dalam rekaman sejarah itu, keduanya menemukan bahwa salah satu pelintas batas antarnegara di Asia Tenggara itu berasal dari Buton, namun tidak ditunjukkan dari Buton manakah orang tersebut berasal. Agaknya, kategorisasi pedagang sekaligus pelayar dalam ilmu pengetahuan Indonesia, khususnya tentang Wakatobi, sedemikian kabur di mata peneliti asing.

Uraian lebih tegas tentang posisi pelayar Buton ditulis oleh Rahman Hamid (2012), Ali Hadara (1987), dan La Ode Rabani (1997, 2010). Ketiga peneliti ini terus berusaha menghadirkan ilmu pengetahuan pelayaran dan perdagangan masyarakat Waktobi di arena pengetahuan Nusantara, Asia Tenggara, dan dunia (La Ode Rabani, 2012). Dalam kerangka berpikir yang hampir sama, James J. Fox (1993) menghadirkan Bajau Communities Sulawesi Tenggara sebagai pencari teripang, sirip ikan hiu, lola, mutiara hingga di perairan Arafuru dan Australia Utara.

Sejauh ini, tulisan-tulisan tersebut masih belum mampu menghadirkan historiografi yang tuntas. Akibatnya, aktivitas pelayaran orang-orang Buton relatif kurang populer dibandingkan Bugis-Makassar di ranah ilmu pengetahuan Indonesia terlebih Asia Tenggara dan dunia. Selain itu, tradisi maritim Wakatobi juga dianggap sebagai "anak bawang” dalam dalam sejarah Indonesia. Dengan demikian, riset maritim mendalam dan komprehensif pun dibutuhkan untuk menambal kekosongan pengetahuan tentang kawasan itu.

Ketiadaan penelitian mendalam tentang navigasi Buton atau Wakatobi, sungguh berbeda berbeda dengan Bugis Makassar, di mana buku navigasi Bugis yang dihasilkan Genne Ammarell (1999) menjadi bukti atas perhatian riset terhadap tradisi maritim mereka. Padahal, masyarakat Wakatobi juga memiliki kosakata-kosakata seperti opala (teknik berlayar bersiku-siku) dan bangunturu (teknik berlayar lurus) yang menjadi kekhasan ingatan kolektif mereka.

Sementara itu, satu karya menarik yang mengungkap kelincahan perahu Wakatobi dalam mengarungi lautan diungkap dalam catatan ekspedisi Alfred R. Wallace, berdasarkan pengalamannya melihat perahu di sekitar Pulau Wangi-wangi yang mendahuluinya dalam perjalanan ekspedisinya ke Maluku. Informasi ekspedisi Wallacea yang tertuang dalam buku Menjelajah Nusantara pada abad XIX itu melengkapi penegasan atas realitas komunitas Wakatobi di perantauan seperti di Bangka dan Belitung, Riau Kepulauan, Pulau Berhala, serta Kepulauan Maluku (hasil diskusi dengan Bambang 
Purwanto, 2013). Keberanian para pelayar Buton melintas lautan dengan perahu-perahu kecil, dibandingkan dengan pelaut-pelaut Bugis yang menggunakan kapal berukuran relatif besar, ini sekaligus menunjukkan akses laut yang lebih luas, khususnya dalam perdagangan.

Luasnya akses perdagangan laut juga terlihat dari perkembangan pemukiman dan perkampungan nelayan dan penyelam di Pesisir Pulau Buton sejak tahun 1920-an. Awalnya, pemukiman itu terbentuk seiring dengan eksplorasi tambang aspal oleh pemerintah kolonial Belanda. Masyarakat sekitar Buton, termasuk Wakatobi dan Toraja, mengisi kebutuhan tenaga kerja di perusahaan tambang Boetoen en Cultuur Maatschapij sebagai pengangkut aspal ke berbagai wilayah Nusantara dengan perahuperahu. Ada juga yang menjadi penyelam untuk kapal-kapal perdagangan yang melayani perdagangan Eropa Eropa dan serta kapal-kapal dan perahuperahu pemuat aspal Buton, seperti Koninklijke Paketvaart Maatschappij (KPM) yang tenggelam. Mereka diupah dengan gulden, sebuah indikasi jika ekonomi uang telah berlangsung.

Selain pemukiman dan perkampungan nelayan dan penyelam di Pesisir Pulau Buton, akses terhadap perdagangan laut juga terlihat dari tiga hal lainnya. Pertama, nama perkampungan pelayar seperti Wagola di Pasar Wajo yang terbentuk ketika komoditas aspal dikomersialisasikan oleh Belanda. Kedua, persebaran bahasa Cia-cia di Pasar Wajo sebagai bukti adanya migrasi masyarakat Binongko. Ketiga, pemberitaan di berbagai surat kabar terkait perahu-perahu layar di pesisir Buton Timur yang memuat barang-barang dagangan para pedagang Wangi-wangi yang dipasarkan di Kepulauan Maluku.

\section{Barang Global di Ruang Ekonomi Lokal: Sejarah Perdagangan Duralex, Rombengan, dan Sepada BMX}

Ingatan tentang duralex tahun 1980-an sama dengan ingatan tentang "sejahteranya" sebagian masyarakat Wakatobi yang terlibat dalam aktivitas perdagangan. Secara khusus, masyarakat Mandati dan Wanci di Wangiwangi, Kaledupa, Tomia, dan Binongko. Sementara orang-orang Bajau dan Binongko berperan sebagai penyedia jasa sewa perahu layar, meskipun tidak banyak secara kuantitas (Irwan Abdullah dan Djoko Suryo, 2014: 32-42). Diakui atau tidak, komunitas tersebut telah melakukan "kompetisi" dalam membangun infrastruktur transportasi laut sebagai jembatan utama yang yang menghubungkan masyarakat di sana dengan daerah atau negara lain (kini mungkin hampir sama dengan tol laut yang direncanakan oleh Prsiden Joko Widodo). Pada saat yang sama, akumulasi kapital terbentuk dan mengalami proses internalisasi yang terwujud dengan mengalirnya barang modal ke kawasan ini dari beberapa daerah dan negara.

Realitas itu memberi efek unik, yakni masuknya barang bekas 
Kehidupan Awak Perahu Lambo

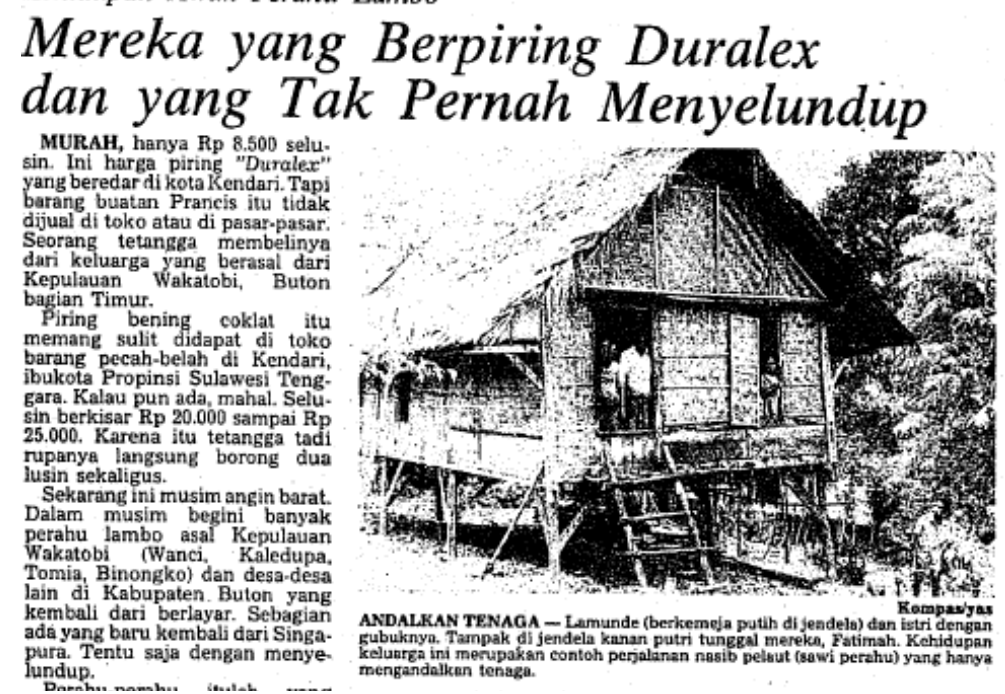

Figur 2.

Rumah pemilik duralex

Sumber: Kompas, 11 Februari

1983

(rombengan) berskala internasional ke struktur ekonomi desa di Kepulauan Tukang Besi, khususnya di Wangi-wangi (Wanci) untuk konteks tahun 1980-an (C. C. Macknight, 1973: 198-208). Masuknya barang-barang tersebut sekaligus membuka kesempatan ekonomi masyarakat lain untuk memasarkannya ke berbagai pulau atau wilayah di Indonesia, khususnya di Indonesia Timur dan Tengah (Kompas, 18 Juni 1998). Salah satunya ialah piring duralex.

Menurut sejarahnya, duralex adalah produk buatan perusahaan Perancis yang tersebar ke Asia Tenggara melalui pelabuhan Singapura dan Malaysia. Di Indonesia, produk ini tidak banyak dikenal, kecuali di Sebatik, Nunukan, dan Kepulauan Riau. Lebih dari itu, duralex adalah barang mewah yang seharusnya ada di ruang keluarga kelas menengah Indonesia. Bagaimana barang itu masuk ke Wakatobi?

Pertanyaan ini singkat sekaligus rumit, mengingat Wakatobi bukan daerah perbatasan, melainkan sebuah kepulauan yang dalam beberapa peta tidak tampak wujud pulau-pulaunya. Daerah ini berada di bagian tengah Indonesia dan jauh dari ibu kota kabupaten, namun "barang-barangnya luar negeri mudah dijumpai," seakan menegaskan fenomena adanya "patungan negara lain" di sana. Kompas 11 Februari 1983, misalnya, menyebut jika pemilik duralex di Wanci, Kaledupa, Tomia, dan Binongko berasal dari kelas sosial bawah yang sebagian di antaranya menghuni rumah gubuk. Identifikasi tersebut kiranya membuktikan bahwa orang yang secara ekonomi tampak lemah (dari bentuk rumahnya), tetapi menggunakan peralatan rumah tangga kelas menengah. Dengan demikian, selain harganya yang murah, ketersediaan duralex di pasaran lokal secara bebas juga mengindikasikan koneksivitas kawasan itu dengan ke pelabuhan Singapura dan Johor Malaysia. 
Hubungan intensif dengan pelabuhan Singapura yang berlangsung reguler mengakibatkan akumulasi barang dagangan di Wakatobi. Barangbarang itu kondisinya tidak mungkin diserap di pasar lokal karena daya beli dan komposisi penduduk sebagai konsumen relatif terbatas. Oleh karena itu, para pedagang memandang perlunya membuka pasar baru di luar Wakatobi. Sejalan dengan itu, "rumor" barang berkualitas itu didengar juga oleh para pedagang Baubau, Kendari, Wawonii, Muna, Lasalimu, Pasarwajo, dan Kolaka hingga ke Sulawesi Tengah.

Di Indonesia Timur, daerah pemasaran baru terbuka di Kepulauan Maluku, Buru, Ambon, dan Timika-Papua. Semua terkoneksi dengan Wakatobi karena dukungan motorisasi perahu layar dan ketersediaan sejumlah kapal motor yang melayani rute tersebut. Seiring dengan membaiknya pertumbuhan ekonomi masyarakat jumlah transportasi laut dari berbagai ukuran melimpah. Sementara akses ke luar wilayah, baik untuk mobilitas penumpang maupun perdagangan, semakin mudah dilakukan dengan pengetahuan navigasi yang baik serta dukungan motorisasi perahu. Dalam kondisi surplus ekonomi ini, komunitas Bajau pun ikut menjadi pedagang, khususnya untuk dipasarkan di Nusa Tenggara, Rote, Alor, dan sekitarnya.

Cerita duralex sebenarnya juga melebar hingga ke ranah sosial. Sejumlah kisah bisa dihubungkan, di antaranya dijadikannya duralex sebagai bahan seserahan dalam prosesi pertunangan warga serta mediator hubungan antara bangsawan dan bukan bangsawan-sebuah tanda bahwa pelemahan tradisi seiring membaiknya tingkat ekonomi. Cerita tentang barang mewah ini meredup ketika operasi besar-besaran tim bea cukai digelar pada tahun 1987 dan disiarkan oleh Televisi Republik Indonesia (TVRI).

Di satu sisi, peristiwa ini juga meredam sementara konektivitas dengan pusat ekonomi sebagai penyedia barang dagangan. Namun, pada saat yang sama, permintaan pasar menjadi sedemikian tinggi di Wakatobi, terlebih dengan kondisi perekonomian negara yang sedang lesu dan mencari jalan keluar dari kemelut ekonomi karena penurunan produksi minyak dan gas bumi. Kondisi itu menjadi peluang bagi para pedagang di sana untuk memulai lagi hubungan dagang dengan Singapura atau podaga woru (Kompas, 29 November 1984). Dalam perkembangannya, revitalisasi hubungan dagang itu berhasil dijalankan, ditandai dengan sejumlah kemajuan seperti peningkatan tonase kapal dan perahu bermesin yang melakukan hubungan ekonomi dengan kota-kota pelabuhan.

Memori masyarakat Wakatobi dengan doe temba (uang sogok) juga tidak terlupakan,. Uang itu berfungsi untuk memuluskan keluar-masuk barang-barang di perbatasan juga pasar-pasar tertentu di kota-kota pelabuhan seperti Kendari, Baubau, Muna, Ambon, Timika, Donggala, Kolaka, Seram, dan Buru. Biasanya, uang ini berasal dari hasil gabungan 
sumbangan para pedagang dan pengikut (punggawa-sawi) dalam perdagangan (Darmawan Salam, 2006). Uang ini sekaligus memperlancarkan arus barang dari Singapura dan Johor Malaysia dengan Wakatobi (Kompas, 10 Januari 1991; Kompas, 18 Juni 1998).

Sementara dukungan transportasi yang terus meningkat dan penggunaan teknologi mesin perahu sebagai penunjang mobilitas barang dan orang menandai terintegrasinya masyarakat Wakatobi ke dalam pusaran tenaga kerja internasional, khususnya Singapura dan Malaysia, di berbagai jenis pekerjaan seperti buruh pelabuhan, bangunan, dan perkebunan. Bagi daerah asal, keterlibatan dalam beragam aktivitas itu menjadi penunjang perbaikan infrastruktur perumahan keluarga pekerja. Di lain sisi, aktivitas itu menggeser penggunaan perahu layar, memperlancar arus mobilitas orang dan barang, serta membuat kaum perempuan sering ditinggalkan para suami dalam waktu lama. Meskipun demikian, ikatan terhadap kampung halaman masih demikian kuat sehingga para perantau lelaki tetap kembali pada istrinya di daerah asal.

Kolektif memori generasi Wakatobi tahun 1980-an sampai 1990-an juga mengisyaratkan betapa bergengsinya sepeda bicycle moto-cross (BMX) pada masanya. Saat itu, setiap anak ingin sekali memilikinya sehingga para orang tua pun harus menitip uang sekitar Rp 50. 000,00 kepada pedagang atau sawi perahu tujuan Singapura dan Johor untuk bisa memperolehnya. Kalaupun ada stok baru yang didatangkan, pasti langsung habis karena banyak anak-anak dan para pedagang yang menginginkannya. Sepeda BMX asal Singapura yang digunakan anak-anak pengusaha angkutan laut itu biasa dikendarai dengan membuatnya seperti "terbang" dengan satu ban depan di sejumlah tempat umum (mirip kontes BMX), seperti di Tugu Pahlawan Wangi-wangi. Lokasi ini adalah ruang terbuka dengan pasir putih, tempat bermain anak muda dan arena pertemuan orang tua yang dilengkapi dengan fasilitas bantea (gardu).

Cerita tentang Tugu Pahlawan sebenarnya adalah ruang umum dan pasar informasi. Pasalnya, area di sekitar tugu ini adalah pasar, tidak hanya dalam arti ekonomi, tetapi juga dalam arti luas; pasar ide atau gagasan, pasar sosial, maupun pasar informasi, sehingga penulis pun menyebutnya sebagai lokasi pergulatan intelektual para pedagang dirumuskan. Warung kopi atau teh (dengan susu manis) ditemani pisang goreng dan makanan khas Wangiwangi, luluta (nasi bambu atau nasi lemang), roti, dan jajanan pasar lainnya menjadi sajian menarik sebagai saksi pergulatan ide-ide dagang dan proses penelaahan berbagai sisi tentang Wakatobi. Kita bisa menyebut nama-nama H. La Saiba, La Mananu, H. Soleh, H. Darimuna, Haji Daud, dan haji-haji lainnya, tiada pagi tanpa menikmati kopi atau teh susu di sana. Hanya saja, tidak banya generasi anak muda yang ikut dalam proses pergulatan itutidak diketahui penyebabnya. 
Masih tentang Tugu pahlawan yang menyimpan banyak cerita terkait sejarah perdagangan Wakatobi. Di sini juga terdapat pelabuhan "bayangan" yang ramai. Arus barang dari Baubau, Jawa, Kendari, dan Ambon diturunkan dan dinaikkan secara bebas dari pelabuhan bayangan ini. Demikian pula, para penumpang naik dari "pelabuhan" ini dengan bantuan sampan atau joson-sampan bermesin. Jenis barang apapun, termasuk ilegal, bisa dengan mudah keluar-masuk dari area ini. Padahal, posisinya hanya berjarak tidak lebih dari tiga puluh meter dari Kantor Komando Rayon Militer (Koramil) dan tidak lebih dari satu kilometer dengan Kantor Polisi Resort (Polres) Wangi-wangi. Tugu ini dalam memori setempat dikenal dengan Tanailandu yang secara harfiah berarti pesisir laut yang dibuat darat (reklamasi).

Barang global di pasaran lokal menjadi bagian penting dari sejarah ekonomi kawasan itu. Cerita tentang BMX, sepeda motor, perahu bermesin, dan barang konveksi bekas namun berkualitas, sama sekali tidak bisa diabaikan dalam sejarah panjang ekonomi Wakatobi. Oleh karena itu, tugu ini menjadi saksi bisu yang ikut "menyaksikan" komoditas itu diperjualkan, dipertontonkan, dan didiskusikan.

\section{Dampak Ekonomi Perdagangan Wakatobi}

Kuatnya modal dan ketatnya kontrol perbatasan melahirkan akumulasi kapital. Akumulasi ini membawa dampak ekonomi dan sosial pada masyarakat Wakatobi. Lahirnya kelas sosial baru, yakni kelas pengusaha angkutan yang bertindak sebagai pemilik modal sekaligus pedagang. Kelas sosial ini lahir dari proses internalisasi yang panjang. Semula mereka adalah para pengikut perahu kemudian para nakhoda yang tidak saja memiliki modal, tetapi juga kemampuan lebih dalam mengatur waktu dalam menuntun perjalanan kapal; dari persiapan keberangkatan sampai pulang kembali ke daerah asalnya.

Proses panjang ini, bila ditinjau dari sisi pendidikan karakter, melahirkan generasi tangguh sebagai pelayar dan pedagang. Interaksi mereka di lautan dalam waktu lama, telah menjadi waktu baik dalam proses pengendapan pengetahuan tentang navigasi, manajemen, dan aturan yang berlaku dalam dunia pelayaran. Kebersamaan dalam satu keluarga di "rumah perahu” telah menyatukan mereka dalam satu nasib dan tujuan sosial; kebersamaan dan kejujuran. Dengan landasan itu pula, perjalanan menjadi lancar dan komunikasi di antara para pedagang sekaligus pelayar menjadi mudah.

Sementara itu, akumulasi kapital yang melahirkan sistem ekonomi global di tingkat lokal memberi nilai ekonomi bagi Wakatobi dan menjadikannya sebagai pusat pasar komoditas barang bekas dan peralatan rumah tangga negara lain, meskipun negara Indonesia tidak hadir atau jauh dari jangkauan kebijakan pemerintahan di Jakarta. Ketika negara hadir dalam bentuk peningkatan pengawasan perbatasan dan optimalisasi 
fungsi bea cukai, industri dalam negeri justru meningkat di tahun 1970-an. Jawa membutuhkan bahan baku seperti rotan, kopra, cengkeh, pala, dan lada. Halnya yang sama juga terjadi dengan industri pertambangan yang membutuhkan sarana angkutan ke berbagai pelabuhan di berbagai daerah. Dalam konteks itu, pelayar dan pedagang Wakatobi meresponsnya dengan menyediakan jasa pengangkutan dan pembelian barang manufaktur yang dihasilkan oleh industri di Jawa seperti peralatan rumah tangga dari plastik, panci, garam, sandal, pakaian, sepeda motor, sepeda, dan lain-lain. Pada titik itu, jiwa pedagang masyarakat tidak pernah surut (Kompas, 20 Oktober 1987).

Proses yang demikian panjang itu telah mengantar pada kemajuan sosial dan ekonomi masyarakat Wakatobi. Berbagai kemajuan infrastruktur transportasi dan bangunan bukan atas prakarsa pemerintah, melainkan sumbangsih masyarakat dari hasil perdagangan dan perantauan, seperti ke Malaysia dan Singapura. Beberapa di antaranya tampak dari peningkatan fasilitas pendidikan dan sosial seperti masjid yang memperoleh pendanaan dari sumbangan se tiap perahu yang melakukan ranso (perdagangan). Mesjid Raya Wanci dan Mandati adalah sebagian contoh dari kasus tersebut, selain mesjid-mesjid yang tersebar di Kaledupa, Tomia, dan Binongko.

Dengan realitas itu, bisa dikatakan bahwa masyarakat Wakatobi sebenarnya telah mandiri secara sosial ekonomi (Kompas, 11 Februari 1987). Akan tetapi, kemandirian ini tidak diimbangi dengan kesadaran akan pentingnya kebersamaan untuk mencapai tujuan-kemakmuran dan persaudaraan. Akibatnya jelas, Wakatobi kehilangan generasi pelayar yang jujur sebagai karakter inti yang menyertai perjalanan dalam membangun ekonomi pedagang masa lalu di masa kini. Hal ini tertutama dipengaruhi oleh kebijakan negara yang mengedepankan sektor agraris dan "janji manis" negara pada kehidupan pegawai negeri sipil (PNS).

\section{Kesimpulan}

Sebagaimana tercatat dalam sejarah perdagangan masyarakat kawasan itu, Nusantara telah menjadi arena aktivitas masyarakat Wakatobi. Adapun daerah tujuan perdagangan yang paling sering didatangi mereka adalah Singapura (Pelabuhan Pasir Panjang) serta Malaysia melalui Johor, Nunukan, dan Sebatik ke Sandakan dan Tawau. Sementara itu, sejarah awal konektivitas kawasan itu dengan Asia Tenggara terbentuk melalaui profesi masyarakat lokal sebagai nelayan dan penyedia jasa angkutan barang. Dalam beberapa kesempatan, mereka juga menjadi penunjuk jalan pengetahuan navigasi ke daerah-daerah tujuan yang dianggap menguntungkan.

Barang-barang yang ada di Wakatobi yang berasal dari negara Asia Tenggara lainnya menjadi bukti kontak langsung yang telah terjalin lama, erat, dan saling menguntungkan. Di samping itu, realitas ini sekaligus 
menjadi penegas ketergantungan kawasan itu dengan kawasan lain yang secara ekonomi menguntungkan. Sebaliknya, kawasan-kawasan lainnya seperti Maluku, Alor, Rote, Kendari, Baubau, Muna, dan sebagian Papua tergantung pada barang-barang rumah tangga, pakaian bekas, bawang putih, pengangkutan, konveksi bekas, dan peralatan rumah tangga lainnya di Wakatobi yang didatangkan dari Jawa, Singapura, maupun Malaysia.

Dalam perkembangannya, episode hubungan dagang dan jasa Wakatobi bisa dilacak sejak abad XVIII, era kolonial Belanda, masa Jepang, hingga kini. Pada masa pascakemerdekaan, khususnya sejak tahun 1960-an, hubungan Wakatobi dengan Singapura dan Malaysia terjadi dalam bentuk perdagangan barang bekas, termasuk perahu bermesin atau kapal yang berlangsung hingga akhir 1990-an. Periode ini berakhir seiring penegakan hukum yang ditandai dengan sejumlah penangkapan perahu lambo, persidangan pelanggaran hukum bea cukai karena peredaran barang bekas luar negeri, serta pembakaran sejumlah barang dari Singapura di Wanci.

Sementara itu, realitas kekinian menunjukkan penurunan aktivitas generasi Wakatobi sebagai pelayar dan pedagang antarpulau. Hal itu terjadi seiring dengan menghilangnya transportasi andalan daerah ini, perahu motor, dalam berbagai ukuran. Revitalisasi mungkin menjadi solusi penting, tetapi kendalanya adalah sumber daya manusia yang tidak lagi tahu tentang manajemen perahu, apalagi menjalankannya tanpa mesin. Di luar itu, masuknya teknologi mesin sebenarnya mempermudah generasi muda mengembangkan ekspansi usahanya. Namun, pilihan ini tidak dijalankan karena pengaruh kuat gaya hidup menjadi PNS dan negara yang demikian dominan berorientasi darat.

Akhirnya, reposisi sosial menjadi penting di tengah ketidakmampuan negara membuat spesifikasi profesi warganya. Satu hal menarik dari realitas ini adalah, pulau-pulau yang dihuni masyarakat pantai, mobilitasnya jauh lebih dinamis dan mampu membuka ruang globalisasi, meskipun berada jauh dari ruang perbatasan dengan negara lain. Ralitas ini, sekaligus menggugurkan pandangan bahwa masyarakat di pulau-pulau kecil jauh dari globalisasi dan arus sejarah bangsanya, yang dalam perkembangan terkini distempel dengan "terdepan, terluar, dan tertinggal".

\section{Referensi}

Soerabaiasch-Handelsblad, 27 Juli 1929.

Soerabaijasch Handelsblad, 16 Februari 1939.

De Indische Courant, 11 Maret 1938.

De Sumatra Post, 26 Maret 1931.

Kompas, 11 Februari 1983.

Kompas, 29 November 1984.

Kompas, 18 Oktober 1985. 
Kompas, 20 Oktober 1987.

Kompas, 20 September 1989.

Kompas, 10 Januari 1991.

Kompas, 7 Maret 1991.

Kompas, 24 Desember 1997.

Kompas, 18 Juni 1998.

Ali Hadara (1987). Sistem Pelayaran dan Perdagangan Masyarakat Kepulauan Wakatobi: Tinjauan Kependidikan Sejarah" (Skripsi, Universitas Haluoleo, Kendari).

Ammarell, G (1999). Bugis Navigation. New Haven: Yale University Press dan Southeast Asia Studies Program.

Benny Baskara, Irwan Abdullah, dan Djoko Suryo (2014). "The Construction and Contestation of Islamic Identity of the Bajo People in Wakatobi Islands, South East Sulawesi, Indonesia," Jurnal Humaniora 26, 1: 32-42.

Booth, A. dan McCawley, P. (eds) (1990). Ekonomi Orde Baru. Jakarta: LP3ES.

Fox, James. J (1993). "Bajau Voyagesto the Timor Area, The Ashmore Reef and Australia”, makalah International Seminar on Bajau Communites, diselenggarakan oleh LIPI, 22-25 November 1993.

Kuhn, Heinrich (1903). "On the Birds Collected on The Tukang-Besi Islands and Buton, Southeast of Celebes," Novitates Zoologicae, 10:18-38.

Koentjaraningrat (2010). Sejarah Teori Antropologi II. Jakarta: UI Press.

La Ode Rabani (1997). Migrasi dan Perkembangan Sosial Ekonomi Masyarakat Kepulauan Tukang Besi, 1961-1987 (Skripsi, Universitas Gadjah Mada, Yogyakarta).

------- (2010). Kota-Kota Pantai di Sulawesi Tenggara. Yogyakarta: Ombak.

Marian, Klamer (1999). "Grammaticalised Quotations in Kambera, Buru and Tukang Besi”, dalam Zeitoun dan Paul Jen-kuei Li (eds), Selected Papers from the Eighth International Conference on Austronesian Linguistics. Taipei: Academica Sinica.

Macknight, C. C. (1973). "The Nature of Early Maritime Trade: Some Points of Analogy from The Eastern Part of The Indonesian Archipelago", World Archaeology 5, 2: 198-208.

Rahman Hamid (2012). Sejarah Maritim Indonesia. Yogyakarta: Ombak.

Sutherland, Heather (2004), "Kontinuitas dan Perubahan dalam Sejarah Makassar: Perdagangan dan Kota di Abad ke-18”, dalam Dias Pradadimara dan Muslimin A.R.Effendy (eds), Kontinuitas dan Perubahan dalam Sejarah Sulawesi Selatan. Yogyakarta: Ombak.

Tagliacozzo, Eric (2005). Secret Trades, Porous Borders, Smuggling and States along a Southeast Asia Frontier, 1865-1915. New Haven dan London: Yale University Press.

Warren, Jim (1978). "Who Were the Balangingi Samal? Slave Raiding and Ethnogenesis in Nineteenth-Century", The Journal of Asian Studies 37, 3: 477490.

Wallace, Alfred R (2000). Menjelajah Nusantara: Ekspedisi Alfred Russel Wallace Abad $X I X$. Bandung: Remaja Rosdakarya.

Velthoen, Esther J. (2002). Contested Coastlines: Diasporas, Trade and Colonial Expansion in Eastern Sulawesi 1680-1905 (Disertasi, Murdoch University, Murdoch).

Wawancara La Mananu di Wangi-wangi September 2014. 